\title{
VÝVOJOVÉ TENDENCE VE SPÁDOVOSTI ZA SLUŽBAMI NA P̌̌́́KLADẼ ZÁZEMÍ BRNA
}

\section{DEVELOPMENTS IN THE TRAVELLING TO SERVICES ON THE EXAMPLE OF THE BRNO HINTERLAND}

\author{
RNDR. JAROSLAV MARYÁŠ, CSC. \\ Katedra regionální ekonomie a správy $\mid$ Dep. of Reg. Economics and Administration \\ Ekonomicko-správni fakulta Faculty of Economics and Administration \\ Masarykova univerzita Masaryk University \\ $\triangle$ Lipová 4la, 60200 Brno, Czech Republic \\ E-mail:maryas@econ.muni.cz
}

\begin{abstract}
Anotace
Př́spěvek je věnován problematice vývoje spádovosti za službami v zázemi Brna. Na základě dotaznikových šetření z osmdesátých let a ze současnosti je provedena komparace změn $v$ relativní uzavřenosti jednotlivých obslužných procesů a jejich hierarchie. Nejvýznamnějši změny přinesly koncentrační tendence $v$ maloobchodě a nový fenomén hypermarkety. Výsledkem byl nárůst dojižd'kové vzdálenosti do hlavnich cílư $v$ některých obslužných procesech, předevšim v dojižd'ce za nákupy průmyslového zboži a za nákupy textilu a obuvi. Došlo rovněž k nárůstu vzdálenosti, na které jsou relativně uzavřeny obslužné procesy, a to prakticky u v̌̌ech zkoumaných obslužných procesů.
\end{abstract}

\section{Klíčová slova}

spádovost za službami, relativni uzavřenost obslužných procesů, vývojové tendence, zázemí Brna

\section{Annotation}

Paper deals with the geographical pattern of higher-than-local retail and services centers and their spheres of influence in part of South Moravian region - hinterland of Brno city. Consumer's migration for retail and services were done, when respondents (the officials of Local Offices) were asked for main and secondary targets of local inhabitants in chosen services. Results were compared with analogical survey from the 80ies. The comparison of changes in the relative closeness of individual service processes and their hierarchy were made. The most significant changes have caused a concentration trend in retail net and a new phenomenon in our retail net - hypermarkets. The result was an increase in commuting distance to the main targets in some service processes, especially in commuting for purchases of industrial goods and purchases of clothing and footwear. There was also an increase in the distance that are relatively closed service processes.

\section{Key words}

travel to services, relative closeness of individual service processes, main trends, Brno hinterland

\section{JEL classification: $Y 80$}

\section{Obecné pozadí}

Vztahy mezi místem bydliště a místem místem maloobchodu a služeb patř́i mezi základní socioekonomické vztahy a dojížd'ku za maloobchodem a službami můžeme považovat za jeden ze základních regionotvorných procesů (viz např. Hampl et al., 1978). Vedle dojížd’ky do škol, která je pravidelným pohybem, se jedná $\mathrm{v}$ našich podmínkách o nepravidelné pohyby obyvatelstva (např. Anděl - Bičík, 1980) a pro jejich analýzu je omezujícím faktorem otázka datové základny. Nedostatek 
vhodných údajů o dojížd’ce za nákupy a službami (neexistuje jejich centrální zjišstování) však nedovoluje detailní poznání těchto procesů mobility obyvatelstva.

Při vymezování zázemí středisek maloobchodu a služeb resp. při obslužných regionalizacích jsou použivány metodické př́stupy založené jednak na využití interakčních modelů, jednak na využití údajů z anketárních šetření. Při použití interakčních modelů (vývoj koncepcí např́. Isard et al., 1998) patří mezi nejčastěji frekventované gravitační modely a modely mezilehlých př́ležitostí (intervening opportunities models). Počátky použití gravitačních modelů pro vymezení spádových území nákupních resp. obslužných středisek můžeme datovat do 20. let minulého století, kdy na základě anketárního šetření prováděného v Texasu formuloval Reilly (1929) tzv. zákon maloobchodní gravitace (později nazývaný Reillyho zákonem).

Pozdější vývoj vedl k zavedení pravděpodobnostního konceptu a rozšíření počtu středisek (původní Reillyho model dovoloval rozdělit území jen mezi dvě střediska). Rovněž dochází ke zevšeobecnění proměnných, např̀. Wilson (1974) zavádí místo počtu obyvatel sídla tzv. produkční proměnnou, což je v podstatě úroveň poptávky v sídle a tzv. proměnnou atraktivity, což je úroveň nabídky ve středisku a rovněž vzdálenost je nahrazována tzv. generalizovanou dopravní funkcí. Ve středoevropských sídelních poměrech se nejčastěji používá tzv. Huffův model resp. jeho zjednodušená varianta typově patřící do skupiny gravitačních modelů somezením, kdy nahrazujeme proměnnou atraktivity zástupnou proměnnou, např. počtem druhů obslužných zařízení, počtem zaměstnaných v maloobchodě resp. ve službách, prodejní plochou nebo maloobchodním obratem (viz např. Maryáš, 1983).

Při vymezování sfér vlivu středisek na základě anketárních šetření se použivají v zásadě dva způsoby:

- anketou ve vybraných zařízeních obslužné sféry vybraného střediska (např. Wokoun, 1983),

- anketou ve všech sídlech zkoumané oblasti (např. Maryáš, 1988).

Většina výzkumů založených na anketárních šetřeních uvádí, že v podstatě v každé hierarchické úrovni existuje zóna intenzivních dojížd'ky, zóna slabší dojížd'ky a oscilační zóna (např. Berry, 1967). Při anketárních šetřeních ve vybraných zařízeních střediska je však problematické stanovení kritérií, kterými určujeme rozsah spádového území i intenzitu vazeb.

Zjišt’ování spádovosti u vzorku populace nejsou bohužel běžná a pokud se v minulosti uskutečnila (např. Výzkumný ústav obchodu Praha, UK Praha, Geografický ústav ČSAV Brno), tak vždy jen na omezených modelových územích. Zatím nejúplnějš́i šetření o spádovosti obyvatelstva za občanskou vybaveností provedl Geografický ústav ČSAV na území ČSR v roce 1979 a na území SSR ve spolupráci s Geografickým ústavem SAV v roce 1978. Toto šetření bylo provedeno přes soustavu místních národních výborů a městských národních výborů, kdy tajemníci národních výborů byli dotazováni na hlavní i vedlejší cíle obyvatel sídla při nákupech potravin, běžného textilu a obuvi, průmyslového zboží (elektrospotřebičủ), léků, knih, nábytku, speciálního výběrového zboží a při návštěvách běžných a speciálních služeb. Z hlediska územního členění byly údaje o spádovosti zjišt’ovány za každou místní část obce (kromě krajských a hlavních měst). Na základě údajů z již zmíněného anketárního šetření Geografického ústavu a na základě údajů ze sčíání občanské vybavenosti 1981 zpracoval Maryáš (1988) studii o střediscích maloobchodu a služeb. Vymezuje střediska základní obsluhy (v ČSSR 419) a základní obslužné regiony (ZOR). Tyto regiony představují rámec, ve které jsou relativně uzavřeny nadlokální obslužné procesy jako jsou nákupy běžného textilu a obuvi, běžného průmyslového zboží, léků, knih, nábytku a návštěvy běžných a speciálních služeb.

V letech 2004 - 2006 bylo provedeno anketární šetření na území moravských krajů, které organizovala Palackého univerzita v Olomouci ve spolupráci s Masarykovou univerzitou (viz Szczyrba et al., 2005). Metodicky navazovalo na dotazníkové šetření Geografického ústavu ČSAV z minulého století a bylo provedeno i parciální srovnání výsledků obou šetření na území NUTS 2 Jihovýchod (Mašíček, 2006), i když sféry vlivu obslužných středisek nebyly vymezovány zcela identicky. 


\section{Metody hodnocení}

Příspěvek vychází z výsledků anketárního šetřeří provedeného v rámci VaV č. IAA301670901, za přispění Grantové agentury České akademie věd. Metodicky anketární šetření navazovalo na obdobná dřive uskutečněná šetření mobility obyvatelstva za službami, provedená jednak na přelomu 70. a 80 . let minulého století Geografickým ústavem ČSAV na území celého Československa (viz Maryáš, 1987 a 1988), jednak rozsahem omezenější šetření prováděné v letech 2004 - 2006 na území Moravy Palackého univerzitou v Olomouci a Masarykovou univerzitou. Obdobně jako ve zmíněných šetřeních byly potřebné údaje zjišstovány korespondenční metodou - rozesíláním dotazníků na obecní úřady, formou cílených dotazů pro zástupce veřejné správy. Otázky byly sestaveny tak, aby mohly být provedeny komparativní analýzy se zmíněnými šetřeními. Byla zjištována dojížd’ka za denními nákupy potravin, nákupy běžného textilu a obuvi, běžnými službami (holičství, kadeřnictví, čistírna aj.), speciálními službami (napr. fotograf, oprava hodin, šití šatů aj.), nákupy léků, nákupy průmyslového zboží (elektrospotřebiče), nákupy knih a $\mathrm{CD}$, nákupy nábytku a nákupy speciálního výběrového zboží (klenoty, auto - moto aj.).

Šetření bylo provedeno přes soustavu obecních úřadů, kdy starostové úřadů, resp. tajemníci byli dotazováni na hlavní, vedlejší a výjimečné cíle obyvatel obce v uvedených procesech. Územní rozsah byl zvolen tak, aby pokrýval Jihomoravský kraj a okresy Kraje Vysočina přiléhající k okresu Brnovenkov. Šetření bylo provedeno v rámci zadaných diplomových prací na území okresů Brno-venkov (Vacek, 2010, Vepřek, 2012), Blansko (Bračok, 2011), Břeclav (Laštůvková, 2012), Hodonín (Laštůvková, 2012), Třebič (Žák, 2012), Vyškov (Bartáková, 2010), Znojmo (Vacek, 2010, Potůčková, 2012) a Žd'ár nad Sázavou (Jirásková, 2012). Vedle těchto šetření probíhalo dotazníkové šetření na vzorku populace ve městě Brně a jeho bezprostředním zázemí - výsledky publikoval např. Kunc, J. et al. 2011.

Po analýzách obslužných procesů byly pro vymezení sfér obslužné spádovosti vybrány ty, které frekvencí využití reprezentují daný hierarchický stupeň, zde jsme se snažili v co nejvyšší míře navázat na předchozí šetření a hodnotili jsme jen nákupy textilu a obuvi, průmyslového zboží (elektrospotřebičů), léků, knih, nábytku, a návštěvy běžných a speciálních služeb (nákupy potravin a speciálního výběrového zboží nebyly hodnoceny).

Výběr obslužných středisek vycházel do značné míry z původní metodiky výběru středisek obslužné spádovosti Československa (Maryáš, 1988), která po analýzách vzdáleností, do které se uskutečňuji cesty za nákupy a službami a podílu obcí uváděných jako hlavní cíle dojížd'ky v obslužných procesech stanovila kritéria pro určení obslužných středisek na základě regionální působnosti. Za postačující byla zvolena podmínka, aby obec byla uvedena jako jednoznačný (hlavní) cíl dojížd'ky alespoň pro jednu obec ve výše analyzovaných obslužných procesech. Rovněž při vymezování sfér vlivu obslužných středisek jsme vycházeli z původní metodiky.

Při vymezování sfér vlivu obslužných středisek bylo hlavním problémem ohodnocení jednotlivých obslužných procesů z hlediska frekvence využívání a tím i určité vyjádření důležitosti procesu pro uspokojování potřeb obyvatelstva. Vycházeli jsme především z počtu uváděných cílů, při předpokladu, že nejvíce cílových obcí je vykazováno u nejčastěji využívaných zařízení občanské vybavenosti, a tedy u nejvýznamnějších resp. současně nejfrekventovanějších obslužných procesů (viz Maryáš, 1988).

Obslužné procesy byly kategorizovány podle intenzity spádu, a to na základě analýzy hlavních cílů, to je cílů uváděných jako cíle převážných nákupů, resp. služeb. Každému obslužnému procesu byl stanoven koeficient podle poměrů počtů hlavních cílů uvedených $\mathrm{v}$ daných obslužných procesech na území vybraných okresů jižní Moravy a počtu cílů v dojížd’ce za nákupy knih, kde byl spolu s nákupy nábytku nejmenší počet hlavních cílů ze zjištovaných základních obslužných procesů. Byly rozlišeny čtyři podskupiny základních obslužných procesủ a pro další hodnocení byl těmto podskupinám pririrazen rozdílný koeficient. 
Poměry byly následující:

nákupy knih : nákupy nábytku : nákupy běžného průmyslového zboží : speciální služby : nákupy textilu a obuvi : nákupy léků : běžné služby $=1: 1: 1,5: 1,6: 1,6: 2,1: 3,2$.

Koeficienty byly potom stanoveny takto:

- koeficient 1 - nákupy knih, nábytku,

- koeficient 1,5 - nákupy textilu a obuvi, běžného průmyslového zboží, speciální služby,

- koeficient 2 - nákupy léků,

- koeficient 3 - běžné služby.

K vybraným střediskům byly ostatní obce prriřazeny na základě převažujícího spádu - kdy celkový relativní význam nejsilnějšího střediska nedosahoval více než dvě třetiny hodnoty celkového relativního významu prvého nejsilnějšího střediska. Ostatní obce, které nevykazovaly dostatečně významnou spádovitost $\mathrm{k}$ určitému středisku byly považovány za oscilační.

\section{Komparace}

Pokud srovnáme územní rozsah zázemí Brna na úrovni základního obslužného regionu se situací v roce 1979, lze konstatovat, že vzrostl vliv Brna na úkor některých okolních středisek v okrese Brnovenkov i okresních měst (Blansko). Tento nárůst vlivu se projevuje především nárůstem oscilačních obcí, které uvádí jako rovnocenný cíl spádu za službami vedle svého střediska rovněž Brno. Klasická střediska v zázemí Brna (Ivančice, Pohořelice, Rosice, Tišnov a Židlochovice) si většinou udržela svá obslužná zázemí, i když v oblastech dobře dopravně napojených na Brno část svého zázemí ztrácí především se to týká Rosic a Velké Bíteše. Nicméně posílením obslužné vybavenosti měst (viz napřs. Szczyrba, Z. et al., 2005) došlo i k nárůstu obslužných regionů některých z těchto středisek, zvláště Pohořelic a Ivančic. Tento fenomén bude vyžadovat ještě podrobné výzkumy provedené na vzorku obyvatelstva v zázemí jmenovaných středisek.

Na druhé straně však došlo k rozvoji obslužných funkcí měst v suburbánní zóně, často podpořených lokalizací velkoformátových prodejen, což se projevilo rozvojem nových dosud neetablovaných obslužných stř̌edisek. Odpovídá to obecným teoriím o nárůstu oboustraných kontaktů mezi střediskem a zázemím v post-industriální etapě rozvoje (viz např. Hampl, 2005). V nejbližší suburbánní zóne Brna patří mezi tato vznikající střediska Kuřim a Modřice a výhledově i Šlapanice.

Porovnávali jsme dále počet hlavních cílů (viz tab. č. 1) a dojížd'kovou vzdálenost $\mathrm{v}$ jednotlivých obslužných procesech (viz tab č. 2). Počet hlavních cílů byl zjišt’ován na celém zkoumaném území tedy Jihomoravském kraji a okresech Třebič a Žd'ár nad Sázavou, dojížd’ková vzdálenost (vzdušná vzdálenost) jen na vybraných modelových územích. Převzali jsme ji ze zadaných diplomových prací za okresy Břeclav (Laštůvková, 2012), Hodonín (Laštůvková, 2012), Třebíč (Žák, 2012), Vyškov (Bartáková, 2010) a východní část okresu Znojmo (Vacek, 2010), celkem se jednalo o 452 obcí. Výsledná hodnota znázorněná $\mathrm{v}$ tabulce č. 2 je váženým průměrem devadesátých percentilů ve jmenovaných územích.

Tab. 1: Poměry počtu hlavních cílů v jednotlivých obslužných procesech $k$ počtu hlavních cílů $v$ nákupech speciálního výběrového zboží

\begin{tabular}{|l|c|c|}
\hline & ČSR 1979 & jižní Morava 2010-12 \\
\hline běžné služby & 5,8 & 3,0 \\
\hline nákupy léků & 2,6 & 1,9 \\
\hline nákupy běžného textilu a obuvi & 5,2 & 1,5 \\
\hline nákupy běžného prům. zboží & 4,5 & 1,4 \\
\hline speciální služby & 1,5 & 1,4 \\
\hline nákupy knih a CD & 1,9 & 0,9 \\
\hline nákupy nábytku & 1,6 & 0,9 \\
\hline nákupy spec. výběrového zboží & 1,0 & 1,0 \\
\hline
\end{tabular}

Zdroj: Maryáš 1988; Bartáková, 2010; Bračok, 2011; Jirásková, 2012; Laštůvková, 2012; Potůčková, 2012; Vacek, 2010; Vepřek, 2012; Žák, 2012; vlastní výpočty. 
Přes masivní nárůst masivní nárůst služeb po roce 1989 - nedošlo $\mathrm{k}$ poklesu dojížd’kové vzdálenosti v jednotlivých oblužných procesech. Změnila se ale hierarchie jednotlivých obslužných procesů za službami - zatímco výskyt speciálních služeb byl na konci 70. let etalonem pro typické městské obslužné středisko, a tedy pro mikroregionální úroveň (viz Maryáš, 1988), v současnosti se tyto služby přiblížily zákazníkovi a patř́i do skupiny procesů mezi nadlokální a mikroregionální hierarchickou úrovní (viz tab. č. 1). Obdobně se změnila i pozice nákupů léků. Nárůst motorismu v posledním dvacetiletí vedl ke změně hierarchické úrovně nákupních procesů vázaných na automobily (v našem dotazníku byly obsaženy $\mathrm{v}$ nákupech speciálního výběrového zboží), které byly ještě $\mathrm{v}$ minulém století považovány za oblužný proces vyšší než mikroregionální úrovně (tamtéž).

Nejvýznamnějši změny ovšem přinesly koncentrační tendence $\mathrm{v}$ maloobchodě a nový fenomén hypermarkety. Výsledkem byl nárůst dojížd'kové vzdálenosti do hlavních cílů v některých obslužných procesech, př̀edevším v dojížd'ce za nákupy průmyslového zboží a za nákupy textilu a obuvi.

Došlo rovněž k nárůstu vzdálenosti na které jsou relativně uzavřeny obslužné procesy - měřeno $90 \%$ vzdáleností, do které se uskuteční veškeré cesty za nákupy a službami - a to prakticky u všech obslužných procesů, kromě již zmíněné dojižd’ky za speciálními službami a nákupy lékủ. Relativní uzavřenost se zvýšila i u denních nákupů potravin.

Tab. 2: Vzdálenost v km, do které se uskutečnilo 90 \% cest za nákupy a službami

\begin{tabular}{|l|c|c|c|c|}
\hline & \multicolumn{2}{|c|}{ ČSR 1979} & \multicolumn{2}{c|}{$\begin{array}{c}\text { modelová území } \\
\text { 2010-12 }\end{array}$} \\
\hline & $\begin{array}{c}\text { hlavní } \\
\text { cíle }\end{array}$ & $\begin{array}{c}\text { všechny } \\
\text { cíle }\end{array}$ & $\begin{array}{c}\text { hlavní } \\
\text { cíle }\end{array}$ & $\begin{array}{c}\text { všechny } \\
\text { cíle }\end{array}$ \\
\hline denní nákupy potravin & 0 & 11 & 3 & 15 \\
\hline nákupy běžného textilu a obuvi & 10 & 18 & 16 & 31 \\
\hline běžné služby & 10 & 14 & 12 & 18 \\
\hline nákupy léků & 11 & 16 & 11 & 17 \\
\hline nákupy běžného prům. zboží & 11 & 20 & 18 & 35 \\
\hline speciální služby & 15 & 20 & 15 & 21 \\
\hline nákupy knih a CD & 15 & 21 & 16 & 36 \\
\hline nákupy nábytku & 15 & 23 & 22 & 36 \\
\hline nákupy spec. výběrového zboží & 20 & 34 & 20 & 36 \\
\hline
\end{tabular}

Zdroj: Maryáš, 1988; Bartáková, 2010; Jirásková, 2012; Lašttưvková, 2012; Potůčková, 2012; Vacek, 2010;

Žák, 2012; vlastni výpočty.

\section{Závěry}

Srovnání současných výsledků s výsledky získanými na konci 70. let dovoluje formulovat následující závěry. Oproti stavu před 30 lety můžeme pozorovat následující vývojové tendence:

- růst důležitosti regionálních metropolí - výsledkem je nárůst regionálního dosahu obslužného zázemí Brna;

- zvyšování obousměrných kontaktů mezi metropolí a zázemím, kdy výsledkem je rozvoj nových dosud neetablovaných obslužných středisek v nejbližší suburbánní zóně Brna;

- masivní nárůst služeb, kdy výsledkem je změna hierarchie některých obslužných procesů dojížd’ky za speciálními službami a dojížd’ky za nákupy léků;

- nárůst motorismu jehož výsledkem je pokles hierarchické úrovně nákupních procesů vázaných na automobily (nákupy speciálního výběrového zboží);

- koncentrační tendence $\mathrm{v}$ maloobchodě a nový fenomén hypermarkety - výsledkem je nárůst dojižd'kové vzdálenosti v některých obslužných procesech, především za nákupy průmyslového zboží a za nákupy textilu a obuvi a nárůst vzdálenosti, na které jsou relativně uzavreneny hodnocené obslužné procesy. 


\section{Literatura}

[1] ANDĚL, J., BIČÍK, I. K některým problémům geografické mobility obyvatelstva. Acta Universitatis Carolinae, Geographica, Supplementum 15 (1980). Praha: Př́rodovědecká fakulta UK, pp. 149-159.

[2] BARTÁKOVÁ, I. Spádovost za službami na Vyškovsku. [Diplomová práce]. Brno: Masarykova univerzita, Ekonomicko-správní fakulta, 2010. $68 \mathrm{~s}$.

[3] BERRY, B. J. L. Geography of market centres and retail distribution. Englewood Cliffs, N.J., Prentice-Hall 1967.

[4] BRAČOK, F.Spádovost za službami ve vybraném regionu. [Diplomová práce]. Brno: Masarykova univerzita, Ekonomicko-správní fakulta, 2011. 87 s.

[5] HAMPL, M., KÜHNL, K., JEŽEK, J. Sociálně geografická regionalizace ČSR. Acta Demographica. 2. Praha, 1978.

[6] HAMPL, M. Geografická organizace společnosti v České republice: transformační procesy a jejich obecný kontext. Praha: Př́rodovědecká fakulta UK, 2005. 147 s.

[7] ISARD, W. et al. Methods of Interregional and Regional Analysis. Ashgate 1998.

[8] JIRÁSKOVÁ, V. Spádovost za službami ve vybraném regionu. [Diplomová práce]. Brno: Masarykova univerzita, Ekonomicko-správní fakulta, 2012. $73 \mathrm{~s}$.

[9] KUNC, J., FRANTÁL, B., TONEV, P. Nákupní spád a vybrané nákupní zvyklosti návštěvníků Galerie Vaňkovka. In Klímová, V., Žítek, V. XIV. mezinárodní kolokvium o regionálních vědách. Sbornik přispěvki̊. Brno: Masarykova univerzita, 2011. s. 47-55.

[10] LAŠTU゚VKOVÁ, H. Spádovost za službami ve vybraném regionu. [Diplomová práce]. Brno: Masarykova univerzita, Ekonomicko-správní fakulta, 2012. $93 \mathrm{~s}$.

[11] MARYÁŠ, J. K metodám výběru středisek maloobchodu a sfér jejich vlivu. Zprávy Geografického ústavu ČSAV, roč. 20, č.3, 1983. s. 61- 80.

[12] MARYÁŠ, J. Dojížd'ka do škol a za službami. In Atlas obyvatelstva ČSSR. Federální statistický úr̆ad - Geografický ústav ČSAV 1987.

[13] MARYÁŠ, J. Nadmistni střediska maloobchodu a služeb v ČSSR a jejich sféry vlivu. [Kandidátská disertační práce] Brno: Geografický ústav ČSAV, 1988.

[14] MAŠÍČEK, P. Střediska regionu Jihovýchod a jejich vybavenost v obchodu a ve službách. [Diplomová práce]. Brno: Masarykova univerzita, Přírodovědecká fakulta, 2007. $64 \mathrm{~s}$.

[15] POTU゚ČKOVÁ, E. Spádovost za službami ve vybraných regionech v česko-rakouském pohraničí. [Diplomová práce]. Brno: Masarykova univerzita, Ekonomicko-správní fakulta, 2012. $76 \mathrm{~s}$.

[16] REILLY W. J. Methods for the study of retail relationships. University of Texas Bulletin. 4. Austin 1929, s. 1-38.

[17] SZCZYRBA, Z. et al. Procesy transformacyjne w handlu detalicznym w ukladzie regionalnym Republiky Czeskiej (modelowa sytuacja w regione Morawy Środkowej). In Kosiedowski, W. (ed.) Regiony Europy Środkowej $i$ Wschodniej wobec globalizacji i integracji miedzynarodowej. Wloclawek, Uniwersytet Mikolaja Kopernika w Toruniu - Wloclawskie Towarzystwo Naukowe, 2005. s. 409-412.

[18] VACEK, P. Spádovost za službami ve vybraném regionu. [Diplomová práce]. Brno: Masarykova univerzita, Ekonomicko-správní fakulta, 2010.75 s.

[19] VEPŘEK, J. Regionotvorné procesy a jejich hierarchie na př́kladě města Brna. [Diplomová práce]. Brno: Masarykova univerzita, Ekonomicko-správní fakulta, 2012. $92 \mathrm{~s}$.

[20] WILSON, A. G. Urban and regional models in geography and planning. Chichester, John Wiley 1974.

[21] WOKOUN, R. Regionálně geografická analýza spádu do obchodního centra města Brna (na př́kladu obchodního domu PRIOR). [Kandidátská disertační práce]. Brno: Př́rodovědecká fakulta UJEP, 1983.

[22] ŽÁK, I. Spádovost za službami ve vybraném regionu. [Diplomová práce]. Brno: Masarykova univerzita, Ekonomicko-správní fakulta, 2012. $93 \mathrm{~s}$.

Př́spěvek vznikl při řešení projektu VaV IAA301670901, za přispění Grantové agentury České akademie vĕd. 